\title{
DIONYSUS AGAINST THE CRUCIFIED: NIETZSCHE CONTRA CHRISTIANITY, PART II
}

\author{
Stephen N. Williams
}

This is the second part of a two-part study of Nietzsche and Christianity (TynB 48 [1997] 219-43). Nietzsche's phrase 'Dionysus against the Crucified' is used as a kind of text for the articles. 'Dionysus' is the principle of life: raw, tragic, joyful, but real, subject to no extraneous principle. 'The Crucified' is the principle of death: anti-natural, symbolising consciousness of sin and foreboding authority of God, imposing a morbid principle on life. This second part is an analytic response to Nietzsche from a Christian point of view. While the course of Dionysus bypasses the reality of human suffering (since attending to it introduces compassion and wrecks joy), the strength of the crucified one lies in his embrace of what is darkest and deepest in reality.

\section{A Matter of Taste}

Nietzsche certainly said many things that disincline us from taking him seriously. A glance at the chapter titles in Ecce Homo makes the point. But not even the kind of egomania exhibited there can exempt us from the task of pondering his contribution. Sentences of superficially bloated self-regard invite sober pause when one investigates both the principal contentions and the historical influence of Nietzsche's work. In Ecce Homo we read:

I know my fate. One day there will be associated with my name the recollection of something frightful-of a crisis like no other before on earth, of the profoundest collision of conscience, of a decision evoked against everything that until then had been believed in, demanded, sanctified. I am not a man I am dynamite. ${ }^{1}$

${ }^{1}$ Ecce Homo, 126. Bibliographical details of Nietzsche's works found in the first part of this article $(219$ n. 1) are not repeated here. Although this article started life as a lecture in the philosophy of religion, this response 
Despite Nietzsche's self-image, the infuriating rhetoric is not empty. He has inspired many to live and rejoice in a posttheistic world to rare effect. He has given many more a good conscience about getting rid of morality, revaluing our values, so that we are no longer slaves to God or to law, but redeemers of our past and creators of our future. ${ }^{2}$

It seems logical to respond to Nietzsche first by trying to disestablish his presupposition. That God is dead is the starting point, not the term, of his thought. Indeed, his authorship does indicate how he and others might get to the starting point. A number of things conspired to make Christian theism incredible to many in the nineteenth century, including the historical-critical shaking of scripture, the naturalistic scientific picture of the world, and the damage inflicted on epistemological assumptions by the critical philosophy of Immanuel Kant. It is both in order, and important enough, to assail these convictions so that Nietzsche's presupposition should be challenged, and the possibility of building on it undermined. But whatever may be said for such a task, it is not on target in relation to Nietzsche or his epigones. A text in The Gay Science tells us why: 'What is now decisive against Christianity is our taste, no longer our reasons' (III.132). Whether or not we are comfortable with his 'now', the sentence is illuminating. Christianity sticks in the craw, never mind the cranium. Here Nietzsche is modern or post-modern enough, whatever his idiosyncrasies.

It may be objected that if we propose to render Christianity tasteful, we are making a fatal concession. Not only are the things of the Spirit folly to those without it, but humanity loves darkness rather than light. It is dangerous to shift the accent from the true to the pleasing. Are we to emulate Schleiermacher's attempt to commend Christianity to cultured despisers, and try to woo them with promises of a tasty infinite? Did not the doctrine of God became compromised in

to Nietzsche may be indifferently characterised as philosophical or theological, both or neither.

${ }^{2}$ Nietzsche's influence and the accuracy of his cultural diagnoses extends far beyond the circles of those who might read him or who are intellectually particularly interested. 
Schleiermacher's theology, being subordinated to the requirements of religious feeling, and the antithesis between sin and holiness become transmuted into the contrast between finite and infinite? ${ }^{3}$ The well-informed will add that Schleiermacher was certainly not popular with Nietzsche and doubtless deserved what he got.

The basic point is well taken. There is plenty in Nietzsche that will not be remotely amenable to such a lure, and there are plenty influenced by him whose cold contempt for Christian faith will only be increased by a proposed move in the direction of ingratiation. For example, not even attention to detail, nuance, balance and subtlety in his statements should forbid us from emphasising Nietzsche's hostility to pity. Apologetic access to the kind of confessed egoism and rejection of pity which is so characteristic of Nietzsche the author, whatever about Nietzsche the man-if this is what we are about-will not be gained by garnishing Christianity with the seductively tasteful. Indeed, apologetic access is generally difficult. What does one say to such a thing as the following?

I have looked in vain even for so much as one sympathetic trait in the New Testament; there is nothing free, benevolent, open-hearted, honest in it. ${ }^{4}$

We might, indeed, go back to the question of truth, giving up any attempt to appeal to the spirit of Christianity. But we also need to think beyond the category of Truth, or, at least, beyond the category as it is widely delimited. This returns us briefly to Schleiermacher.

One can understand why Schleiermacher (even if adjudged mistaken) could be appealing, compared to other proponents and presentations of Christianity. Here we need to go back to Augustine. Augustine had realised that Truth is worthy of worship only if it is also Beauty. ${ }^{5}$ It was a point

\footnotetext{
3I have Schleiermacher's Speeches on religion in mind here.

${ }^{4}$ The Antichrist, sec. 46.

5In light of what is said later of Nietzsche, who plundered some of the Greeks, it is worth recording a remark made by J. Burnaby (Amor Dei [London: Hodder \& Stoughton, 1938] 157): 'But to the Greeks and to the Greeks alone had been given that extraordinary combination of visual
} 
learned well by such medievals as Bonaventure, but apparently lost in much post-Reformation thought. When Schleiermacher located the essence of religion in feeling rather than in knowing or doing, he struck out along a perilous path, but the implicit orientation towards beauty in this scheme of things should have reminded those theologians who had neglected their Jonathan Edwards, that Beauty is worth pondering, along with Truth and Goodness. ${ }^{6}$ Roman Catholic thought, most notably in the shape of von Balthasar's work, has freshly appropriated the theme in contemporary Christian thought; Orthodoxy has sought to sustain it formally in the liturgical practice which so constitutes its genius. But just a generation ago, Moltmann could comment that 'Karl Barth was the only theologian in the continental Protestant tradition who has dared to call God beautiful'.7

Even Barth, however, is sparing on this point, if it does not seem perverse to ascribe such a characteristic to the author of the Church Dogmatics. ${ }^{8}$ Formally, the discussion of beauty is subsumed under the theme of divine glory. Barth holds that it is not a leading theological concept, or a primary motif in the understanding of God. 'We speak of God's beauty only in explanation of His glory. It is, therefore, a subordinate and auxiliary idea which enables us to achieve a specific clarification and emphasis.' From this, Barth moves on to conclude on a related point re the theological task that 'reflection and discussion of the aesthetics of theology can hardly be counted a legitimate and certainly not a necessary task of theology'. This conclusion, however, certainly needs to be challenged, for it presupposes a stable and not a contextual understanding of the theological task. We may well need to say

sensitiveness and intellectual passion which led to the discovery that if truth is to be worshipped, then truth is beauty.'

${ }^{6}$ Schleiermacher does not systematically relate feeling and beauty in his Speeches, but the addresses as a whole appeal to a kind of aesthetic sensibility.

7J. Moltmann, Theology and Joy (London: SCM, 1973) 58.

${ }^{8}$ His treatment is found in Church Dogmatics 2.1 (Edinburgh: T. \& T. Clark, 1957) 650-66. The quotations that follow in this paragraph are from pp. 653 and 657 respectively. 
more about beauty and the associated theological task that Barth eschews may well be in place.

Moltmann himself rightly, though not ostentatiously, nudges us beyond Barth. Like Barth, his rubric is the divine glory and, like Barth, the connection between joy and beauty is fundamental. 9 Moltmann writes: 'We experience God's dominion equally as his glory and as his beauty and as his sovereignty...The beautiful in God is what makes us rejoice in him.' One need not capitulate for one moment to Nietzsche's assault on the Christian pretension to truth (it is full of irrational nonsense) or on the Christian pretension to goodness (it is a slimy mass of ressentiment) to look further afield, and realise that the idea that Christianity should celebrate divine beauty is virtually off Nietzsche's conceptual map. Yet he himself was concerned for joy and, in connection with it, beauty. It is worth delving a little into this, though it may initially seem like a distraction. ${ }^{10}$

\section{What Nietzsche Wanted}

The Prologue to Thus Spoke Zarathustra (TSZ) sets the scene for Zarathustra's teaching in what he knows to be a post-theistic world. Book I ends triumphantly: 'All gods are dead: now we want the Superman to live' (104). However much Zarathustra has struggled to discern this, there is a greater struggle still to impart it. But it must be done: 'Once you said "God" when you gazed upon distant seas; but now I have taught you to say "Superman"' (109). The Superman must do what God once did,

${ }^{9}$ Theology and Joy, 58-64. The quotation that follows in this paragraph is from p. 62.

${ }^{10}$ The foregoing may give the impression that Christianity is understood here, by the author of this article, in terms of Platonic categories of Beauty, Truth and Goodness. However, no such schema is being imposed. The Augustinian relation of Truth and Beauty is not presupposed, still less is any enquiry offered into whether beauty should be regarded as a quality inhering in holiness, whether goodness is equivalent to holiness, etc. The vocabulary of 'beauty' is introduced because (a) it is worth theological attention, however it is to be related to other concepts, and (b) the Platonic triad is a convenient way of identifying what Nietzsche does and does not attend to in his critique of Christianity. 
but his task is rather harder. For there is a legacy to be overcome, the existence of given law-tables. In the Prologue, Zarathustra spoke of the one 'who smashes their tables of values...the law-breaker...the creator' (51). God only had to create; Zarathustra's company must destroy and create. In the first of the discourses after the Prologue ('Of the Three Metamorphoses'), the importance of the subject is underlined. In opposition to 'thou shalt', we must create freedom for the creation of new values. For this, a metamorphosis of the spirit is needed. Zarathustra is not the creator of new values. His job is harder. He is the revealer of the freedom to create new values, who must let his fellow-man do so, and by which his fellowman will truly live. Zarathustra is thus the revealer of true humanity.

'When I visited men', says Zarathustra, with the task of creation in mind, 'I found them sitting upon an old self-conceit. Each one thought he had long since known what was good and evil for man...I disturbed this somnolence when I taught that nobody yet knows what is good and evil-unless it be the creator!'11 The task of new creation here committed to us is given de facto metaphysical weight by adducing the terminology of good and evil. No wonder Zarathustra is a burdened soul. The burden has grown heavy even as he climbs and climbs and makes his discovery of the eternal recurrence of all things. This discovery superficially looks like an eschatological dawn in the story of Zarathustra and any who wake up to the idea. The Prologue, while programmatic, did not portend the revelation of this doctrine. The words quoted at the end of Book I ('All gods are dead: now we want the Superman to live') are followed by the eschatological proclamation: 'Let this be our last will one day at the great noontide!' The eschatological expectation is even more arresting than the declaration. Part Two, immediately following this, is set out under the eschatological rubric, quoting from words in Part One: '-and only when you have all denied me will I return to you. Truly, with other eyes, my brothers, I shall then

${ }^{11}$ 'Of Old and New Law-Tables', the longest and perhaps most important chapter in TSZ, sec. 2, 214. 
seek my lost ones; with another love I shall then love you.' But here is the rub. If the doctrine deserves to be celebrated, transmission to disciples is nevertheless an issue. The discovery of eternal recurrence at the beginning of Part Three may enlighten Zarathustra, but does not solve that problem.

That becomes increasingly clear in Part Three. 'Love', said Zarathustra, in the chapter on 'The Wanderer', 'is the danger for the most solitary man' (175); 'pity', we read in the next chapter, 'is the deepest abyss' (177). There is turmoil in the heroic soul. Consciousness of the possibility of love and how this bears on the responsibilities of teaching weighs heavily on the mind (181). 'My contempt and my bird of warning shall ascend from love alone' (197); 'Grief and dejection' are enemies (225). To put it in terms of breathtakingly crude domestication: the problem of relationships and of communication remain for the prophet of eternal recurrence. Zarathustra's animals, in a chapter which has them luminously expound the teaching ('The Convalescent') would have him rejoice at his discovery and its content:

New lyres are needed for your new songs. Sing and bubble over, O Zarathustra... For your animals know well, O Zarathustra, who you are and must become: behold, you are the teacher of eternal recurrence, that is now your destiny (237).

But do the animals know what is involved? The problem in communicating is now overshadowed by the problem posed by the teaching itself, compounding intolerably the problem of human relations. Because if 'man recurs eternally', then 'the little man recurs eternally!...Ah, disgust! Disgust! Disgust!'.12 Nietzsche surely means to imply that the revelation of eternal recurrence thwarts, as much as glorifies, the teaching 'all gods are dead, now the Superman must live'. For this last

12Sec. 2, 236. The words of C.S. Lewis ('The Weight of Glory' in Screwtape Proposes a Toast and other pieces [London: Fount, 1965] 109) come to mind: 'It is a serious thing to live in a society of possible gods and goddesses, to remember that the dullest and most uninteresting person you can talk to may one day be a creature which, if you saw it now, you would be strongly tempted to worship, or else a horror and a corruption such as you now meet, if at all, only in a nightmare.' 
proclamation presupposes a novel historical future. Eternal recurrence presupposes the continued future of the religious and petty-moral past as well. Even if the teaching is no piece of metaphysical realism, it casts its shadow exactly as such realism would.

At the end of Part III, 'The Great Longing' is followed by 'The Second Dance Song', at the end of which the clock strikes twelve.

One! O man! Attend

Two! What does deep midnight's voice contend?

Three! 'I slept my sleep,

Four! 'And now awake at dreaming's end:

Five! 'The World is deep,

Six! 'Deeper than day can comprehend.

Seven! 'Deep is its woe,

Eight! 'Joy - deeper than heart's agony:

Nine! 'Woe says: Fade! Go!

Ten! 'But all joy wants eternity,

Eleven! ' - wants deep, deep, deep eternity!'

Twelve!

The knowledge of eternal recurrence is eternal joy to the heart. The triumphant apocalypse of the closing chapter of Part III, 'The Seven Seals (or: The Song of Yes and Amen)', concludes its seven sections with the refrain:

Oh how should I not lust for eternity and for the wedding ring of rings - the Ring of Recurrence! Never did I find the woman by whom I wanted children, unless it be this woman whom I love: for I love you, O Eternity! For I love you Eternity. 13

One might be forgiven for wondering whether the cause of Christianity in its relation to anti-Christianity in the modern world is much served by quoting the dramatic indulgences we have met. We respond with two points, the second of which is the more important.

\footnotetext{
${ }^{13}$ Since TSZ was initially completed in three parts, I have treated this as its climax. However, as the first part of the article indicates (see 228-30) the material in Part Four is significant.
} 
Firstly, Nietzsche thinks he has apprehended a thing of beauty which is a joy for ever. The prospect or the act of creating values per se may have an aesthetic appeal, but it is born of a necessity brought on by the death of God, whose alternative is pessimism, resignation or despair. Amor fati is possible and its appeal can be gauged by consulting Stoics and Spinoza, but the form of amor fati elicited by eternal recurrence makes of necessity a rich and scintillating phenomenon. Eternity is the meeting point of Nietzschean joy and love, the eternity of eternal recurrence. Joy and love can only respond like this to a thing of beauty. There is more than a dash of Platonism here in the anti-Platonic Nietzsche. Platonism posits a world beyond and behind the world of appearances, while Nietzsche's dionysian world is the world of flux and appearance. But Nietzsche requires something of the emotional force of Platonism to pull off eternal recurrence. The theological content and moral effect of Platonism are utterly alien to Nietzsche, but its emotional potential is not. The concept of 'eternity' indicates at least a family resemblance in the two cases. I am not assuming that eternal recurrence is a piece of metaphysical realism. One can take it differently. On that account, what delights Nietzsche is the metaphorical, symbolic presentation of the character of necessity, so that he can joyfully embrace it, not resign himself to it. The metaphor, symbol or vision is required for, or achieves, the existential affirmation of life, not stoically but joyously, in the midst of tragedy.

It is indeed tragedy, however, when the eternal God of Christian faith does not remotely present the appearance of an object of joy and love, as far as Nietzsche is concerned.14 Whatever fault lay on Nietzsche's side, and whatever may be

${ }^{14}$ In light of our later reference to Barth on Leibniz, and the reference to Leibniz in Part I of this article (232 n. 25) it is worth recording the manifest sincerity of Leibniz' conclusion to his 'Principles of Nature and Grace, Founded on Reason': 'Since, too, God is the most perfect and the most happy and consequently the most loveable of substances, and since pure true love consists in the state which causes pleasure to be felt in the perfections and happiness of the beloved, this love ought to give us the greatest pleasure of which a man is capable, when God is the object of it... God is...very loveable and gives great pleasure' (etc.). See G.W. Leibniz, Philosophical Writings (London: Dent, 1934) 29-31. 
attached to his twentieth-century successors, one can not help feeling that Christians have frequently portrayed a God who is truth, but not beauty, who has goodness, but no appearance of joy. ${ }^{15}$ Christians can appreciate the instinct, even when it surfaces in its peculiarly and idiosyncratically Nietzschean form, that requires a representation of transcendence to generate appropriate existential modes. More specifically, Nietzsche must have seen this-worldly affirmation-the unreserved embracing of this world-as perceptibly threadbare without the consolation of Eternity. ${ }^{16}$ Yet, in Nietzsche's scheme of things, eternal recurrence functions to further this-worldly flight. How this is so takes us to the second point.

The confluence of love and joy at the point of apprehending 'eternity' is significant because we miss it at any other point. The singular and personal apprehension of deep eternity enables the fulfilment of love and joy, but the presence of others is inimical to it. Why? The answer is best given with reference to Schopenhauer. The connection between compassionate love and suffering which Nietzsche discovered in Schopenhauer's work irked Nietzsche profoundly. He was at one time deeply moved and influenced by the romantic pessimism exuded by The World as Will and Representation and Schopenhauer's influence persisted throughout his literary career, even if it took the external form of an antitypical philosophy to his own. Schopenhauer, working with a metaphysically complex notion of the 'will', had portrayed life and world in terms of seething, striving, restless, purposeless activity, biologically rooted in the drive to life, expressed overtly in sexuality, and impelled from unconscious depths.

${ }^{15} \mathrm{I}$ am as concerned here for popular and homiletic presentations as for written and academic presentations. G.K. Chesterton once commented on a French gendarme who could make mercy appear colder than justice; although this is rather more specific than the target of this article, it is the same area, nonetheless.

${ }^{16} \mathrm{TSZ}$ attacks Christian other-worldliness from the beginning, but an other-worldly ethos clings to the belief in eternal recurrence, partly because it is naturally imaged in height (follow the narrative in "The Vision and the Riddle', 176ff) but partly because it smacks of the kind of metaphysical consolation that is very much 'behind' the appearance of the world. 
The self is implicated, without being enmeshed, in all this. In aesthetic contemplation, the ego somehow manages to transcend its own ontological environs. It is also capable of the appropriate response to life: resignation, willing the cessation of strivings, a kind of Buddhistic nihilism. Further, it is extremely capable of compassion, the only spring of moral action-a profound and active identification with the sufferings of the other. Here, then, we have the optimal shape of human life objectively formed by Schopenhauer's metaphysic: one loves; one wills the renunciation of existence; thus, one is saved.

Nietzsche thought that Schopenhauer's philosophy was possible only as a retrogressive post-Enlightenment reappropriation of what should be discarded, namely, a form of the Christian world-view, pessimistic, bleakly compassionate, soteric. Nietzsche insisted on the presence of what he regarded as tragedy, and on the need to embrace it willingly, but our response must be governed by joyful affirmation of life. Hence suffering and joy define the parameters of profound human experience. But now we surely arrive at a crucial point: Nietzsche, roughly speaking, substitutes joy for compassion. Love of some kind may be directed to deep eternity. But love directed to co-humanity involves, to the point of being defined by, compassion. Love incarnate is compassion. And incarnate compassion is killjoy. It now becomes clear why the expulsion of Christianity from conscience, consciousness and culture is the absolute precondition of the health of humanity. If love and joy can co-exist with reference to eternal recurrence, though the eternal God is not its possible object, they can not co-exist with reference to this-worldly companions, for compassion must inevitably lurk.

It is relatively easy to formulate a critique of Nietzsche at this point. His is a vision of superhumanity, dwelling in 'azure solitude'. 17 This phrase understandably struck Karl Barth in relation to Nietzsche, and he cites it more than once in his discussion of Nietzschean anthropology as a philosophy of man without co-humanity. ${ }^{18}$ Barth is fundamentally right here. Of

${ }^{17}$ Ecce Homo 106.

${ }^{18}$ Church Dogmatics 3.2 (Edinburgh: T. \& T. Clark, 1960) 231-42. 
course, one must not slide out of responsibility for a broader survey of Nietzsche's thought by concentrating on Zarathustra. The excesses of this work can be viewed as philosophically superfluous poetic extravaganza which must not be confused with the main point. Nevertheless, Nietzsche's other literature scarcely encourages us to suppose that he is enamoured of a society whose ethos is that of compassionate love. Nietzschean society, it seems, is regulated by the exercise of power, will and relative justice, though doubtless he could hope to harness and even bring to a form of rational expression tendencies which are personally cruel and socially destructive. ${ }^{19}$ Of course, the idea of truly socialised humanity, including one that is compassionate, is not uniquely Christian, though Nietzsche argued both that (a) the survival of belief in moral objectivity was inconsistent with belief in the death of God, and that (b) the survival of the virtuous status of compassion, or of belief in its inalienable existential presence in the structure of our humanity, were Christian remnants. Still, the humdrum criticism that Nietzschean anthropology is radically individualist must be allowed its place. 20

The question that arises now, however, is whether the co-existence of joy and love is possible in relation to the things and relationships of unenchanted earth. What a relational anthropology does not possess per se are the elements of joy, love, eternity and beauty which fulfil Zarathustra. The problem can be posed better by turning, as was signalled at the end of Part I of this article, to a scene from C.S. Lewis.

${ }^{19}$ But see Stephen N. Williams, 'Life Without Hippocrates: the Vision of Nietzsche', Ethics \& Medicine 12.2 (1996) 27-32.

${ }^{20}$ Of course, what may be a humdrum criticism certainly contains no humdrum subject-matter. "The one principle of hell is- "I am my own"', said G. Macdonald; see C.S. Lewis, Surprised by Joy (London: Collins, 1955) 170. The saying is at the least suggestive. Barth refers to a line running from the sixteenth century through Leibniz and Hegel to the nineteenth century (Church Dogmatics, loc. cit. n. 18), a thesis developed at considerable length in Protestant Theology in the Nineteenth Century (London: SCM, 1972) Part 1. But it is not clear to me that Leibniz is so deeply implicated in all this. 


\section{The Problem of Joy}

It would certainly be wrong to translate a dialogue and narrative in Prince Caspian into a prosaic theological proposal.21 But it contains a sequence that naturally introduces the suggestion that in the presence of Christ the dionysian has its place. This suggestion can certainly be linked to the wider conviction that paganism includes a praeparatio verae religionis, and is thus not the pure negation of Christianity. Either joy or the longing for joy (the identity and distinction involved here are noted in Lewis' Surprised by Joy) is prefiguringly present in paganism, and Christianity brings fulfilment.22 On Lewis' terms, Nietzschean joy is certainly connected to Christian joy along such lines. But Lewis' scene from Prince Caspian also introduces us to a question about joy that leads us back to the pitfall of compassion. It is one thing for mortals to rejoice in the presence of Aslan, but Aslan is not mortal; could Aslan take mortal form and so rejoice? Jesus was a man of sorrows. Dionysian joy, even if we admit is as a human possibility for homo Christianus in the most tentative and slender fashion, seems a world away from him. ${ }^{23}$ Of course, Dionysus may be tripping us up here: Are we not springing from Lewis' tale to the supposition that Christian humanity can take on board Dionysus, simply because Nietzsche is in view, and perilously neglecting to exercise any theanthropological control? Perhaps there is a risk, but my point is less to suggest the possible presence of the dionysian in Christian experience than to indicate the fall-out from its apparently necessary absence from

${ }^{21}$ On indirect communication in Lewis, see P.L. Holmer, C.S. Lewis: The Shape of His Faith and Thought (New York: Harper \& Row, 1976) 61-67.

${ }^{22}$ Lewis is one of the three authors, the others being Bonaventure and Bonhoeffer, whose detailed exploration would profit us in developing the ideas in this article. Lewis' remarks on joy are scattered throughout this work. G. Sayer (Jack: a Life of C.S. Lewis [London: Hodder \& Stoughton, 1997] 146) equates joy with the 'mystical experience of beauty'.

${ }^{23}$ The concept of Dionysus must suffer the fate of many other concepts in this article, that of being unanalysed. I take it here in a reduced form: it is the notion of exuberant and abandoned joy in the face of reality and in the midst of strife. At risk of misrepresentation, David's whirling gyrations before the ark point the way (2 Sa. 6.14). 
christology. Nietzsche, in his later authorship, tried in some respects to separate Jesus from the Christian herd. If we want to identify with Jesus on Nietzsche's terms (a thought-experiment that will strike many as far from edifying) then Nietzsche dooms Christianity afresh to being awash with love and estranged from joy. How so?

For the most part, Nietzsche did not exempt Jesus himself from criticisms of Christianity. ${ }^{24}$ Then the following sentence appeared in Beyond Good and Evil:

It is possible that within the holy disguise and fable of Jesus' life there lies concealed one of the most painful cases of the martyrdom of knowledge about love: the martyrdom of the most innocent and longing heart which never had sufficient of human love, which demanded love, to be loved and nothing else, demanded it with hardness, with madness, with fearful outbursts against those who denied it love' (208).

The Antichrist presents us with a sustained interpretation of Jesus. Its vagaries are not to the point here, but we quote the following:

This 'bringer of glad tidings' died as he lived, as he taughtnot to 'redeem mankind' but to demonstrate how one ought to live. What he bequeathed to mankind is his practice: his bearing before the judges, before the guards, before the accusers and every kind of calumny and mockery-his bearing on the Cross (157-58).

Indeed, '[i]n reality there has been only one Christian, and he died on the Cross' (161). And the meaning of that life and death? Certainly not the deliberately perverted and despicably perverse Christian doctrine of redemption. No: 'True life, eternal life is found-it is not promised, it is here, it is within you: as life lived in love, in love without deduction or exclusion, without distance' (151). That is pain. Eternal life within...Jesus got that right. Yet Jesus is Zarathustra gone wrong. We see how

${ }^{24}$ The earlier works are especially in mind, from Human all too Human onwards. 
Zarathustra and Jesus, a pair of free spirits, bear rather remote comparison. ${ }^{25}$ Zarathustra perceived, even was tempted in the direction of, Jesus' destroyer: pity. Pity can swallow you up. ${ }^{26}$ But Zarathustra lived longer than Jesus, and was therefore wiser. ${ }^{27}$

Taking intellectual history seriously does not mean giving the time of day to everything in it, and there is no need to admit the serious possibility that Nietzsche understood Jesus' psychology, that he was near the mark in his picture of the pathos of Jesus' life, soul and suffering, the pathos of a love universally extended and little requited, or that we need muse too long on the contrasts between the historical Jesus and the unhistorical Zarathustra. The most generous way of dismissing Nietzsche at these points is to say that his understanding is wholly undialectical, possible only because of his self-image and image of the human condition. That is, Nietzsche's is an incredible portrayal of Jesus' passivity. Nevertheless, the problem of Jesus returns us to the antithesis of joy and compassionate love. If Zarathustra lacks the second for the sake of the first, does Jesus at all lack the first for the sake of the second? If we are still hung up on Dionysus, we may suspect that there is nothing dionysian about Jesus. Even Aslan, the lord before whom one dances, is not the leader of the dance. What does this say about Christ as the pattern of our humanity? If Christ is our true humanity, is there something lacking in our earthly joy that is simply there in paganism-for better or for worse, to put matters polemically? If so, we may conclude that the scene in Prince Caspian is fictitiously removed from reality at more levels than one. Anything which existentially corresponded to it in real life would actually cause a rupture, not a realisation, of the Christian ideal and vision of things.

${ }^{25}$ Nietzsche (The Antichrist, 154) pays Jesus the compliment of calling him a 'free spirit' after a fashion.

${ }^{26}{ }^{\prime}$ Where are your greatest dangers? In pity' (The Gay Science, III sec. 271).

${ }^{27}$ 'Truly, too early died that Hebrew... He himself would have recanted his teaching had he lived to my age! He was noble enough to recant! But he was still immature' (TSZ 98-99). This work begins with reference to Zarathustra's thirty years and ten ('Prologue', 39). 
Even more than TSZ it would then be fiction fabulously factitious.

How should one respond here? Joy in the presence of the Lord is an Old Testament theme, the Psalms and Isaiah advertising it with peculiar strength. The Lord himself can rejoice. ${ }^{28}$ If things are very different in the pages of the New Testament, then the nature of human religion has changed with the evaporation of human joy. Has the world grown pale and grey with the breath of the Galilean who is identified as both God and man but lacks an experience of joy once analogically common to both parties? A survey of the New Testament demonstrates clearly the religious permanence of human joy, and the nexus of themes that we encounter in the Farwell Discourses of John's Gospel-joy, friendship and love-is richly revealing of the mutual joys of the creator, creature and mediator. Joy, for all, is set in the heart of relationships of love, and God, who is love (though we do not meet that proposition here) is relational in his own immanent trinitarian being. If God is passible, it is not on the ground of those immanent relations, which conduce to joy. ${ }^{29}$ If there is suffering, it has to do with sin and with sacrifice, the price paid by love for the achievement of creaturely joy when a phenomenon extrinsic to the immanent divine being impinges-the phenomenon of sin. Nietzsche sought joy as an individual expelled from the garden of theistic belief. Christians rejoice in being embraced by and embracing the other when sin is forgiven. Because joy is grounded in the immanent reality of God and the friendship of our brethren, it is not of the purely other-worldly, prospective and anticipatory kind. ${ }^{30}$ God is present in our world as its immanent and thisworldly depth, not just as its remote future. ${ }^{31}$ Love for and joy

${ }^{28} \mathrm{Zp.}$ 3:17, a particularly beautiful expression of this, has been described as 'the John 3:16 of the Old Testament' (O.P. Robertson, The Books of Nahum, Habakkuk, And Zephaniah [Grand Rapids: Eerdmans, 1990] 339).

${ }^{29} \mathrm{Admittedly}$, this is a condensed and fleeting systematic presentation of the theology of John 14-17 in its wider context on the points at issue.

30This is not to deny an anticipatory and prospective element, nor to side with Bultmann's interpretation of the realised eschatology of joy, as does von Balthasar, Truth is Symphonic: Aspects of Christian Pluralism (San Francisco: Ignatius, 1987) 153. 
in brother and friend exists in the mode of actuality, not just of hope. ${ }^{32}$

Scripture is economical, though not silent, on the joy of Jesus. That is not just because his joy is primarily prospective. It is surely because we do not more than glimpse the face he turned towards the Father in communion and prayer, where radiant joy is reflected. Instead, we see the face turned towards us and the sorrow reflected there because of what he saw in us. Hence the appearance-that is, the manifestation, not the unreality-of suffering and pain. Nietzsche made Jesus somewhat in his own image, a sensitive and isolated soul which, however, shrivelled, where Nietzsche aspired to expand. Nietzsche eventually says nothing, and apparently knows less, about the relation of Father and Son. He does not believe in incarnation, and so does not discern the face of God in the features of Jesus. How else could his God be a detestable lawgiver, while Jesus is a pathetic lover? He does not know that Jesus moved from joy (filled with delight day after day, rejoicing always in his presence) unto joy (he will drink again from the fruit of the vine when the kingdom of God comes) and that, therefore, joy can hardly be alien to his being. ${ }^{33}$ For the Son of Man who is Son of God to move from one to the other required, uniquely, incarnation for the sake of atonement. ${ }^{34}$ Because of this saving history, the joy of the creator Lord and the joy of the creature who dances in his presence are not allowed their plenary expression nor their normative place in the life and time of Jesus between baptism in the Jordan and death on Calvary. ${ }^{35}$ Suppose that the dionysian moment in

31I interpret this in the traditional sense, rather than a widespread modern panentheistic sense of immanence.

32Lewis (The Great Divorce [London: Bles, 1945] 88) tries to preserve the balance here: 'Every natural love will rise again and live forever in this country: but none will rise again until it has been buried.'

33It seems to me that the christological application of this text from Prov. $8: 30$ is warranted only if we do not confuse personification with hypostatisation.

${ }^{34}$ This is not to take sides on the question of whether or not the incarnation would have occurred had there been no need for atonement.

${ }^{35}$ The motif of 'dance' is pervasive and quite effectively used by $C$. Pinnock in Flame of Love: A Theology of The Holy Spirit (Downers Grove: 
Narnia represents a genuine and valid Christian and human possibility. Failure to derive it from Jesus' humanity is surely explicable in some such terms. The historical Jesus we meet in the records is on the way from Jordan to Jerusalem, and that path is taken so that the joy of the divine Lord and the human creature be attained, not forfeited.

Our whole discussion has been massively concessionary in relation to Nietzsche, allowing him to set its terms and presuming that although his thought is unrepresentative in form it is not unrepresentative in instinct. Having said as much, it is right to add that the foregoing account of the suffering love of Jesus in the service of eternal joy does no more than correct his perspective at this point. More needs to be said. And one who says it to good effect is Dietrich Bonhoeffer. ${ }^{36}$ Bonhoeffer wants to place Christian practice beyond good and evil. The knowledge of good and evil is a sign of the fall and of disunion with our creator, since we are created to know God alone, who is our good. Jesus, the true man, does not live by the knowledge of good and evil.

He lives and acts not by the knowledge of good and evil but by the will of God. There is only one will of God. In it the origin is recovered; in it there is established the freedom and the simplicity of all action' (30).

One must allow something here for a cryptic presentation of the kind one finds in Bonhoeffer's The Cost of Discipleship with his occasional gestures towards the gnomic or rhetorical which delay our appropriation of the theological point. But there is a good point. What we easily miss, including at those times when we confidently affirm that Jesus could have sinned (because we conceive of no tempting or testing that is humanly different from our own) is the sheer force of Jesus' adherence to the will of God, the holy, the Father. ${ }^{37}$

IVP, 1996) though he often exhibits a frustrating unreadiness to demonstrate theological convictions by a more detailed exegesis.

36D. Bonhoeffer, Ethics (New York: Macmillan, 1965).

37Too often, the case for Jesus' posse peccare envisages him struggling exactly as we do. While Bonhoeffer's christology is undoubtedly patient of various interpretations, it contains the healthy possibility of portraying a 
The freedom of Jesus is not the arbitrary choice of one amongst innumerable possibilities; it consists on the contrary precisely in the complete simplicity of His action, which is never confronted by a plurality of possibilities, conflicts or alternatives, but always only by one thing. This one thing Jesus calls the will of God' (30).

It is one thing to say, and to emphasise, that Jesus loved and suffered, wept and pitied. It is another to regard him as buffeted, vulnerable, redeemed or rescued by his God from the grave after a storm-tossed existence marked mainly by passive endurance of human vice. Amor patris actually requires more strength than amor fati. For the wise and prudent know that impersonal fate is logically non-manipulable; but to learn that the personal God and heavenly Father will not be manipulated either, and then to love his will with the same passion as the Father wills his will, is to summon one's humanity to its highest fulfilment in radical faith, in the face of what looks like its deepest annihilation. Jesus must contemplate the most extreme suffering of separation and even of mortal annihilation; yet, he does not flinch from determination by the will of God. Anyone who thinks that a humanity shaped in obedience to and under the lordship of this person is feebly pathetic, is plain blind. The 'moral imperative' at the heart of discipleship is more strenuous than anything Kant came up with; the 'existential imperative' at the heart of discipleship is more humanising than anything Nietzsche can even imagine. New Testament ethics and their practitioners have been called all kinds of weakly things. But the ethical injunctions of the New Testament writers must not be divorced from the participatio and imitatio Christi which constitute their ontological setting. Christian morality and Christian ethics, if we are to employ those terms, are unintelligible save in terms of the formation of Christ in us, risen in the concrete humanity which he assumed at incarnation. The incarnation of God reveals to us that reality is ordered to the glorification of humanity and of creation as the will of God who is alone glorious. When we capture this vision,

true humanity which nevertheless differs from ours in its relation to the possibilities of good and evil. 
that of Nietzsche appears as broken, fragmented and rather sick, instead of integrated, unified and profoundly beautiful.

So we return to beauty. The cross is unavoidable, but that the plenitude of divine love and joy should appoint and allow suffering and pain is the revelation, not the obscuring, of beauty. Bonaventure, picking up the theme of wisdom mentioned earlier in relation to Proverbs, apparently stood in the tradition that understood divine glory as the beauty of divine wisdom. Forma sapientiae est mirabilis, et nullus eam aspicit sine admiratione et ecstasi. 38 The ecstasy in question has actually been dubbed dionysian, and not just mystical, though we leave it undefined here ${ }^{39}$ But it does not by-pass the cross: the path to wisdom is through the burning love of the crucified one. Whether or not this constellation of wisdom, beauty, joy, cross, love, is rightly ordered, these things require our attention. Perhaps Nietzsche attacked a Christianity whose vision had become severely blinkered, a faith which allowed for too little in the way of joy and beauty, and so distorted eternity and wisdom. Not that the rehabilitation of such a Christianity is the guarantee of apologetic success. It is more the guarantee of Christian flourishing, the fruit being yielded in its season.

\section{Conclusion}

In Nietzsche's godless world, love and joy meet only at the point where eternal recurrence is affirmed. The horizontal aspect of things, the world of mundane human reality, can not generate either. Nietzsche's is just one form of godlessness. Ex professo, scientific socialism (in its strictly materialistic doctrinaire form) is a different one and sheer autarchy, completely ungrounded in even the thought of eternal recurrence, is another. 40 In every case, one can engage in suitable Christian argumentation, but I think it is equally

${ }^{38}$ Quoted in H.U. von Balthasar, The Glory of the Lord, volume II (Edinburgh: T. \& T. Clark, 1984) 270.

${ }^{39}$ Ibid., 273.

${ }^{40}$ Arguably, I have made too much of this teaching. And yet it indicates as nothing else the pathos in Nietzsche's thought, quite apart from its avowed centrality. 
important to limn the contours of Christian life and selfunderstanding not in order to gain the apologetic advantage ad hoc, but in order to clarify the Christian vision and further Christian formation. It is possible to do so by describing Christian faith, hope and love. It is also possible to take the first two named fruit of the Spirit, love and joy, which seems an appropriate course in relation to Nietzsche. This article is, at best, a pointer in the direction of what we might undertake. 41

'For Bonaventure', said von Balthasar, 'it is vital that ecstasy, even in its Dionysian aspects, is not a flight out of the world that leaves it behind, but rather the opening of the world for God, or more precisely the revelation of the fact that the world has already been grasped by God.' 42 Even if Bonaventure's thought is regarded as imperfect, his life exemplified the impossibility of living either in a purely otherworldly or in a purely this-worldly dimension. ${ }^{43}$ One can come away from Nietzsche with the impression that while he knocks other-worldly religion, he actually fosters an other-worldly attitude with the ecstasy of eternal recurrence. ${ }^{44}$ The vocabulary here is, admittedly, a bit unhelpful. Because 'hope' looks forward to what is unattained, the hope of heaven seems to imply an other-worldly religion. In fact, just as our hope, like our faith, is in truth, 'in God' (1 Pet. 1:21), so joy and love are directed to the God we believe we know now, and the divine

${ }^{41}$ The closing words of the first part of this article (TynB 48 [1997] 219-43) were perhaps ambiguous, though it did not occur to me that I might be misinterpreted as hinting at the comparable influence of my own work (243)!

${ }^{42}$ Op. cit., 273.

${ }^{43}$ This is well-attested, though it is not von Balthasar's theme. Bonaventure was a Franciscan, and the potential for contemporary alliances between spirituality and service here can be considered by consulting L. Boff, Saint Francis: A Model for Human Liberation (London: SCM, 1985). But 'otherworldly'/'this-worldly' terminology is ambiguously unsatisfactory, and certainly the suggestion is not that 'spirituality' be assigned to one dimension and 'service' to the other.

${ }^{44}$ From the beginning of TSZ Nietzsche pits his plea for 'loyalty to the earth' against the religious 'afterworldsmen'. The point of attributing otherworldliness to Nietzsche here is to challenge his success in fostering positivism. Surely a form of positivism is his logical creed. 
and dominical association of God and neighbour ensures a thisworldly religion. But there is the cross. 45

The problem with Dionysus is that joyful and tragic affirmation is one course open to him, and the course that he takes, but the reality of human suffering is by-passed in life, for attending to it apparently introduces compassion and wrecks joy. 46 The strength of the crucified one lies in his embrace of what is darkest and deepest in reality. Those who have tasted something of the forces of evil-and have not placed human action in the category of 'beyond' it-are rightly drawn to a scene where evil and good seem in historical confrontation as starkly as we find anywhere. And even when traditional notions of atonement are excluded, the more closely one looks at evil, the more intuitively one will reach out for characterisations that are in the orbit of traditional atonement theories. 47 Some insight into and some experience of the way things are conduces far more effectively to the appropriation for oneself of Christian truth today, than a relatively disengaged disputation on the case for Christian theism. 48 If

\footnotetext{
${ }^{45}$ One wonders whether it is a defect in Lewis' work that any attempt to get round dualisms of this and the next world in relation to love, joy, the natural and the beautiful, fail to reckon sufficiently with the religious significance of the cross. This could be fruitfully pursued in relation to a critique of Nietzsche, particularly with Lewis' repeated words in The Screwtape Letters (London: Fontana, 1955) that God is a 'hedonist at heart' $(112,127)$.

${ }^{46}$ The point that Nietzsche ignores real evil by reverting to 'aristocratic kitsch' is very effectively made by G. Fraser of Wadham College, Oxford, in some unpublished material.

${ }^{47} \mathrm{I}$ can not prove the point here, though it depends on distinguishing between the valid and the crude in the presentation of traditional doctrines. It is when evil is experienced as unspeakably defiling that the biblical idea of cleansing ceases to offend; it is when such evil is experienced as within all of us that the idea of personal cleansing can not be ignored; it is when such cleansing is in prospect, that the idea of substitution should not be dismissed.

${ }^{48} \mathrm{Of}$ course, a variety of strategies are open vis-a-vis Nietzsche. His version of Christianity as anti-life depends on translating humanity out of the realm of creation-fall-redemption. Within that realm we can challenge the anti-life criticism by affirming human sexuality, and by granting that conflict and strife indeed cause the human organism to flourish, but are
} 
one opposes a Christian vision of things to Nietzsche's vision of things, it is because Nietzsche's vision of things has made such a mark, and the doctrine of eternal recurrence is its perfectly fitting symbolic expression even when that teaching itself has not been particularly or directly influential. One does not advance a Christian vision of things on the assumption that people still have visions of things; the lack of any vision, including a Nietzschean one, seems more characteristic of (dare we say it?) the modern Westerner than the possession of a grand perspective. 'Christian vision' comes into play because a living and strong appropriation of Christian truth is impossible without the passion that goes beyond bare affirmation. Nietzsche's passion should make us jealous; but if we imitate, it will be the fruit of another's passion.

rightly directed towards the dominion of nature not the domination of people. 